\title{
Yellow Sugarcane Aphid, Sipha flava (Forbes) (Insecta: Heteroptera: Aphididae) $)^{1}$
}

Gregg S. Nuessly²

\section{Introduction}

The yellow sugarcane aphid, Sipha flava (Forbes), was described from Illinois by Forbes in 1884. Originally referred to as the 'sorghum aphis' and placed in the genus Chaitophorus (Forbes 1884), it was later moved into the genus Sipha (Davis 1909). Sipha includes 12 species of grass feeders, at least four of which occur in North America north of Mexico. The yellow sugarcane aphid causes damage to sorghum, sugarcane and several species of pasture grass (Median-Gaud et al. 1965, Kindler and Dalrymple 1999).

\section{Distribution}

The yellow sugarcane aphid is thought to be a North American native. It is known from the Caribbean, and North, Central and South America. It occurs throughout temperate and subtropical North America (including the Hawaiian Islands) and north into the states of New York in the east and Washington in the West (Blackman and Eastop 2000).

\section{Life Cycle and Description}

Sipha flava reproduces without mating (i.e., parthenogeneticly) in warm climates and produce live young. Females mate with wingless males in areas with cold winters. Nymphs go through four instars before molting directly into the adult stage (i.e., no pupal stage). Development from nymph to reproducing adult takes about 8 days on $S$. bicolor (Hentz and Nuessly 2004), but 18 to 22 days on sugarcane. Females produce one to five nymphs per day for about 22 days on average on Sorghum bicolor and sugarcane.

These aphids prefer to feed on the lower surfaces of leaves, lining up along the parallel leaf veins of their grass hosts. S. flava tolerates dense populations on the leaves and usually begin to move to other leaves only after the host leaf has become mostly yellow and begun to die. Honeydew produced by the feeding aphids collects on lower leaves and supports growth of sooty mold fungi.

It is not uncommon to find Melanaphis sacchari ('white sugarcane aphid') in small populations dispersed among S. flava on sugarcane leaves.

1. This document is EENY-354, one of a series of Featured Creatures from the Entomology and Nematology Department, Florida Cooperative Extension Service, Institute of Food and Agricultural Sciences, University of Florida. Published: August 2005. This document is also available on Featured Creatures Website at http://creatures.ifas.ufl.edu. Please visit the EDIS Website at http://edis.ifas.ufl.edu.

2. Gregg S. Nuessly, Entomology and Nematology Department, Institute of Food and Agricultural Sciences, University of Florida, Belle Glade, FL.

The Institute of Food and Agricultural Sciences (IFAS) is an Equal Opportunity Institution authorized to provide research, educational information and other services only to individuals and institutions that function with non-discrimination with respect to race, creed, color, religion, age, disability, sex, sexual orientation, marital status, national origin, political opinions or affiliations. U.S. Department of Agriculture, Cooperative Extension Service, University of Florida, IFAS, Florida A. \& M. University Cooperative Extension Program, and Boards of County Commissioners Cooperating. Larry Arrington, Dean 


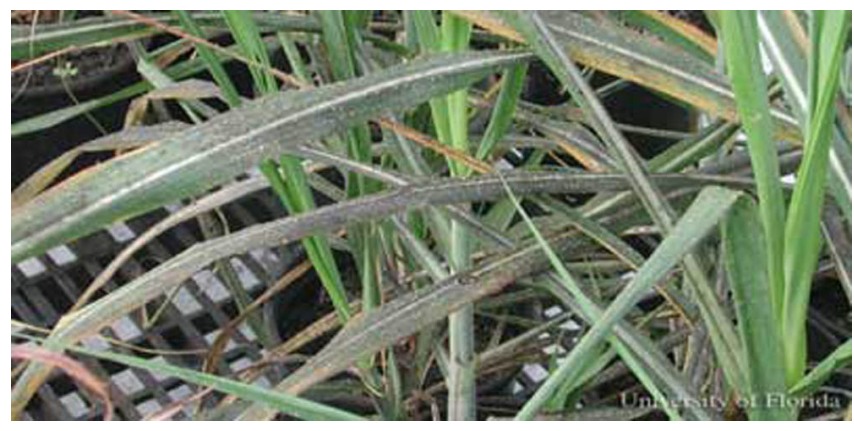

Figure 1. Sooty mold fungus growing on honeydew deposited on lower sugarcane leaves by yellow sugarcane aphids, Sipha flava (Forbes). Credits: Gregg S. Nuessly, University of Florida

Interestingly, $S$. flava does not produce an alarm pheromone, but it responds to the alarm pheromone of $M$. sacchari by quickly falling from the plant.

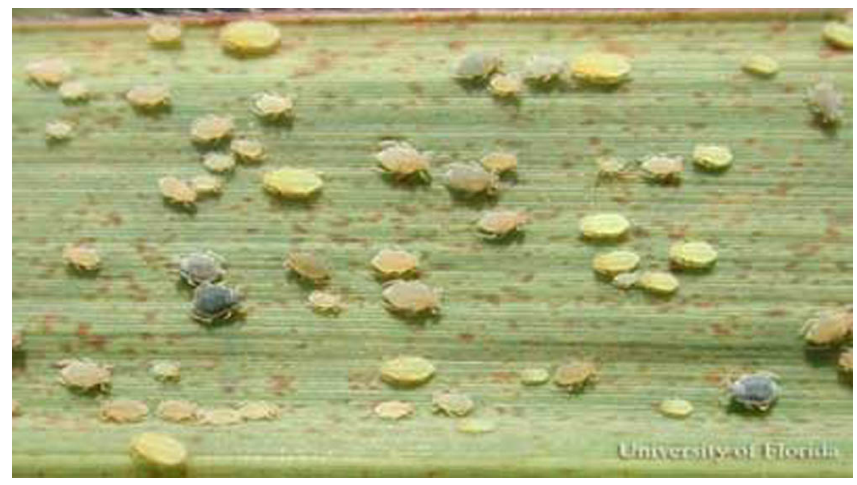

Figure 2. Mixed colony of white, Melanaphis sacchari, and yellow, Sipha flava (Forbes), sugarcane aphids on sugarcane, Saccharum officinarum. Credits: Gregg S. Nuessly, University of Florida

Wingless yellow sugarcane aphid adults and nymphs are straw to bright yellow to light green in color with two double rows of dusky colored spots down the top of the abdomen. Rows of spots are also present along the lateral margins of the abdomen. Yellow sugarcane aphids are yellow on sugarcane. $S$. flava is covered with short, stiff hairs. The cornicles (siphunculi) are reduced to slightly elevated pores. Adult females can be separated from large third instar nymphs by the presence of a small, rounded, knobby cauda adorned with several hairs at the end of the adult abdomen. Winged and wingless adults are 1.3 to $2.0 \mathrm{~mm}$ long. Winged females have yellow abdomens with the same spots described above and darker head and thorax than wingless females.

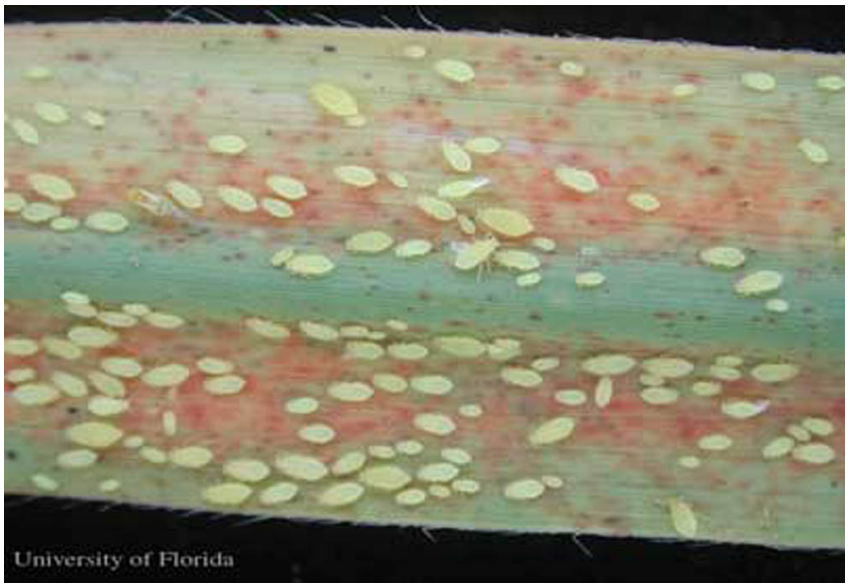

Figure 3. Yellow sugarcane aphids, Sipha flava (Forbes), on sugarcane, Saccharum officinarum.

\section{Host Plants}

Cultivated crops known to host $S$. flava include corn, rice, sorghum and sugarcane. Yellow sugarcane also reproduces on lawn and pasture grasses. This species is known from the following genera of Graminea: Digitaria, Hordeum, Oryza, Panicum, Paspalum, Pennisetum, Saccharum, Sorghum, Triticum and Zea. It is also recorded from the genera Carex and Cyperus in the Cyperaceae.

\section{Damage}

Feeding initially results in yellowing and reddening of leaves, depending on host plant and temperature. Prolonged feeding can lead to premature senescence of leaves and plant or stalk (sugarcane) death. Yield reductions usually occur due to feeding damage to early plant growth stages, including reduced tillering (Hall 2001). However, yield loss from late season feeding damage to sugarcane has also been documented (Miskimen 1970). Many sugarcane cultivars frequently have six to eight leaves below the terminal leaves. Yield can be reduced by $6 \%$ following the S. flava-induced death of as few as two of those leaves within the first three months of growth (Nuessly and Hentz 2002a). Chlorosis and death of three pairs of those leaves due to aphid feeding can result in $19 \%$ yield loss. Yellow sugarcane aphid also transmits sugarcane mosaic potyvirus (Blackman and Eastop 2000). 


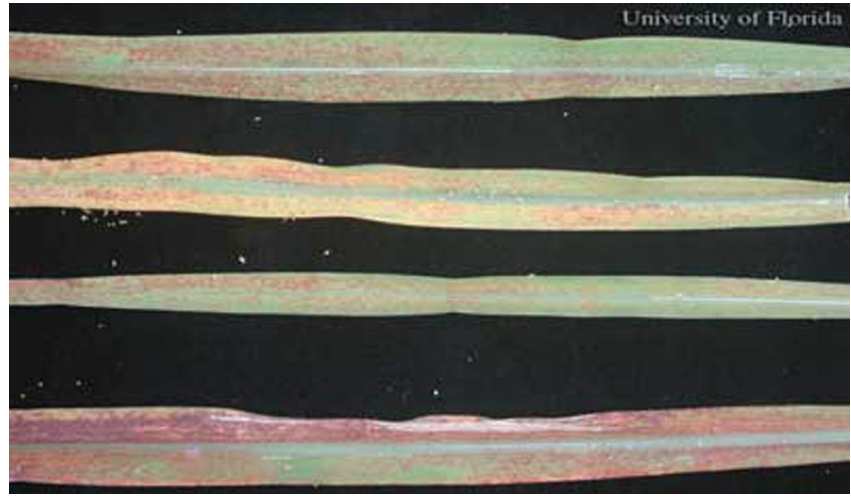

Figure 4. Sugarcane, Saccharum officinarum, varietal responses to yellow sugarcane aphid, Sipha flava (Forbes), feeding: yellowing, reddening, necrosis. Credits: Gregg S. Nuessly, University of Florida

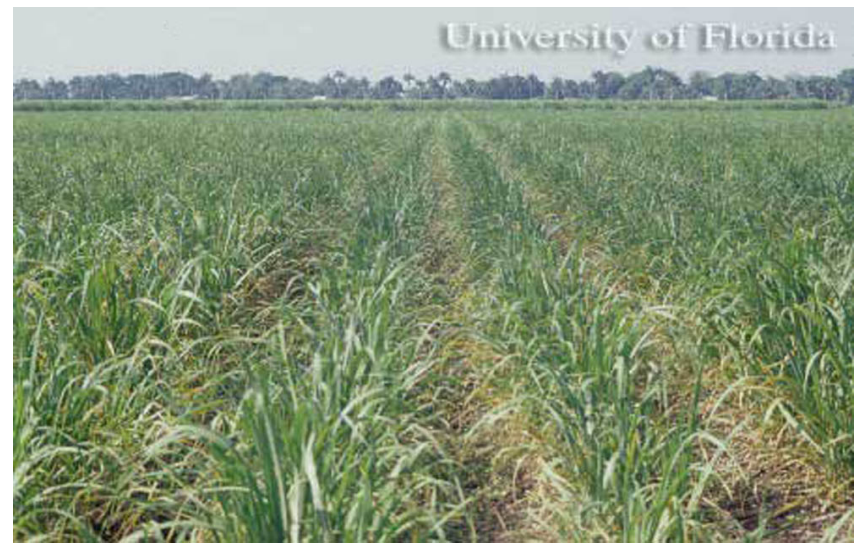

Figure 5. Yellow sugarcane aphid, Sipha flava (Forbes), damage to young sugarcane, Saccharum officinarum. Note yellow leaves displayed as stripes from field edge. Credits: Gregg S. Nuessly, University of Florida

\section{Natural Enemies}

Natural enemies, including arborial earwigs (e.g., Doru terminatum), 10 species of ladybird beetles (Coccinellidae, including Diomus terminatus), several species of flower flies, predacious ants (e.g., the red imported fire ant, Solenopsis invicta), and young spiders can greatly reduce yellow sugarcane aphid populations, but this may not occur before the aphids have caused plant damage.

Parasitism by native parasitic wasps occurs rarely and none are known in Florida. An aphidiid parasitoid collected from France, Adialytus ambiguus (Haliday), was released and subsequently established in Hawaii in 1991 where it initially killed less than $10 \%$ of the yellow sugarcane aphids (Anon). Temperatures above $95^{\circ} \mathrm{F}$ and heavy rainfall from

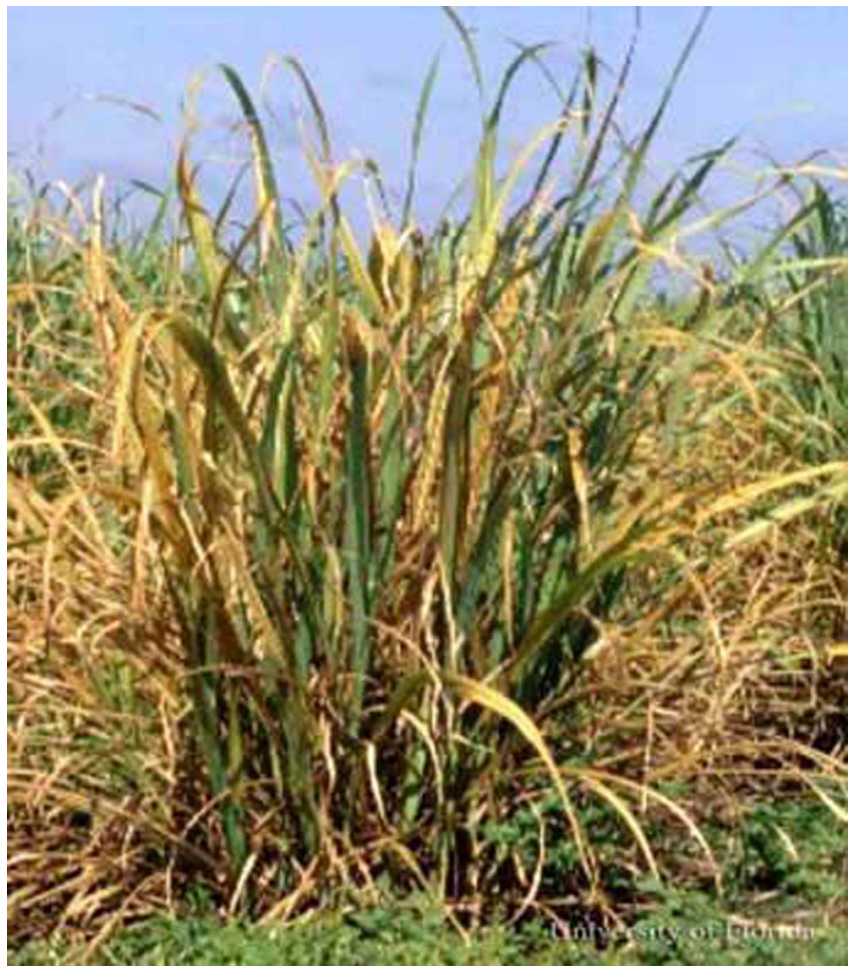

Figure 6. Damage to sugarcane plant in field, by yellow sugarcane aphids, Sipha flava (Forbes). Credits: Gregg S. Nuessly, University of Florida

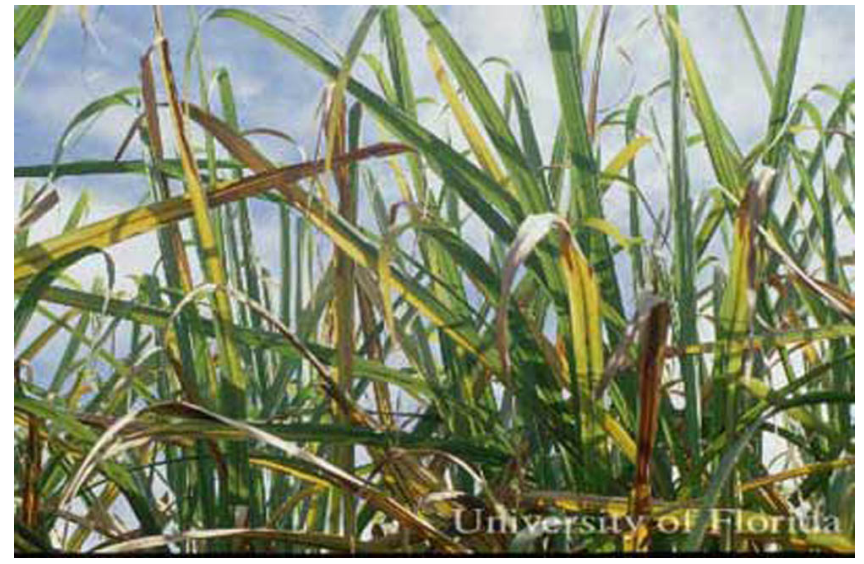

Figure 7. Yellow sugarcane aphid, Sipha flava (Forbes), damage to tops of late season sugarcane, Saccharum officinarum. Credits: Gregg S. Nuessly, University of Florida

summer storms also are effective at reducing yellow sugarcane aphid populations.

\section{Management}

Most yellow sugarcane aphid damage in Florida occurs during the spring and mid to late fall. Aphid population development within a crop should be closely monitored to insure that natural enemies are keeping the density low enough to prevent premature 


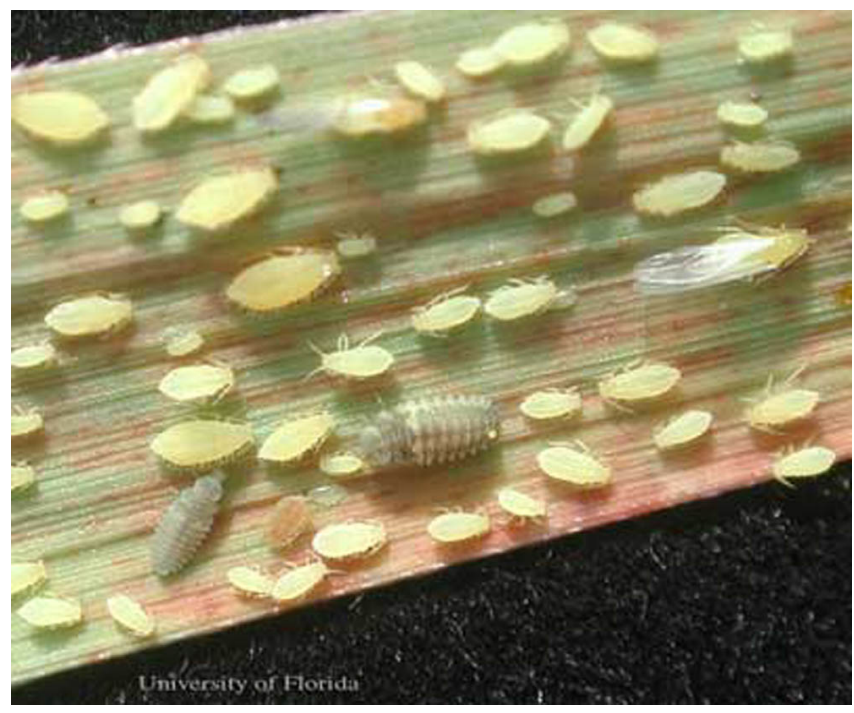

Figure 8. Diomus terminatus ladybird larvae feeding on yellow sugarcane aphids, Sipha flava (Forbes), on sugarcane, Saccharum officinarum. Credits: Gregg S. Nuessly, University of Florida

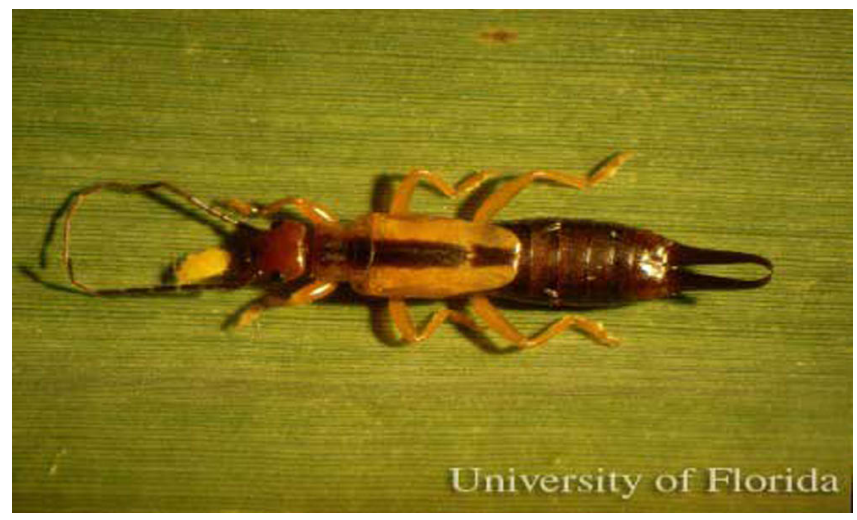

Figure 9. Male Doru terminatum earwig feeding on yellow sugarcane aphid, Sipha flava (Forbes), on sugarcane, Saccharum officinarum. Credits: Gregg S. Nuessly, University of Florida

leaf yellowing and death. Insecticides are available that provide effective $S$. flava control (Nuessly and Hentz 2002b) should natural enemies or weather fail to keep populations in check. Timing of insecticide treatment is critical to avoid yield or stand loss. Aphid numbers quickly build to numbers too large to count for sampling purposes. Sugarcane leaf damage symptoms are a good indicator of season long growth and yield effects and works without having to count aphids. An infestation that leaves just four live leaves beneath the top visible dewlap leaf (youngest fully developed leaf) with more than $50 \%$ green tissue (i.e., average of two to three badly damaged leaves) is still enough to reduce sugar content at harvest by up to $6 \%$. Significantly greater yield reductions occur with each additional pair of leaves showing $>50 \%$ aphid damage. Several insecticides are labeled for foliar application against this aphid. Use of cultivars resistant to yellow sugarcane aphid feeding is an important management strategy. Sugarcane clones under development that show at least partial resistance to damage caused by yellow sugarcane aphid feeding include CP98-1417, CP98-1481, CP98-1497, CP99-1542, CP99-1893, CP99-1894 and CP99-1896.

Many sorghum varieties of sorghum are susceptible to $S$. flava feeding (Starks and Mirkes 1979). Resistant hybrids of sorghum and sudangrass are grown in Florida primarily for grazing and silage.

For more management information please see, Insect Management Guide for Sugarcane (http://edis.ifas.ufl.edu/IG065).

\section{References}

Anonymous. Yellow Sugarcane Aphid Project. Yellow sugarcane aphid (Sipha flava [Forbes]). Plant Pest Control. Department of Agriculture, State of Hawaii. http://www.hawaiiag.org/hdoa/pi_ppc_ bio_ysaphid.htm (1 August 2005).

Blackman RL, Eastop VF. 2000. Aphids on the World's Crops: An Identification and Information Guide, 2nd Edition. John Wiley \& Sons Ltd., England.

Davis JJ. 1909. Biological studies on three species of Aphididae. Washington DC. US Dept. Agriculture.

Forbes SA. 1884. Recent Observations. Plant-Lice - Aphides. Thirteenth Report of the State Entomologist on the Noxious and Beneficial Insects of the State of Illinois, May 31, 203 pp.

Hall DG. 2001. Notes on the yellow sugarcane aphid Sipha flava (Homoptera: Aphididae) and the lady beetle Diomus terminatus (Coleoptera: Coccinellidae) in Florida. Journal of the American Society of Sugar Cane Technology 21: 21-29.

Hentz MG, Nuessly GS. 2004. Development, longevity, and fecundity of Sipha flava (Homoptera: 
aphididae) feeding on Sorghum bicolor.

Environmental Entomology 33: 546-553.

Kindler SD, Dalrymple RL. 1999. Relative susceptibility of cereals and pasture grasses to the yellow sugarcane aphid (Homoptera: Aphididae). Journal of Agricultural and Urban Entomology 16: 113-122.

Medina-Gaud S, Martorell LF, Robles RB. 1965. Notes on the biology and control of the yellow aphid of sugarcane, Sipha flava (Forbes) in Puerto Rico. Proceedings of the 12th Congress of the International Society of Sugarcane Technology. San Juan, Puerto Rico, March 28-April 10: 1307-1320.

Nuessly GS, Hentz MG. 2002a. Feeding effects of yellow sugarcane aphid on sugarcane. Journal of the American Society of Sugar Cane Technology 22: 126-127.

Nuessly GS, Hentz MG. (2002b). Evaluation of insecticides for control of yellow sugarcane aphid on sugarcane, 2000. Arthropod Management Tests 27: F113. Entomological Society of America. http://www.entsoc.org/Protected/AMT/AMT27/ index.asp (1 August 2005).

Starkes KJ, Mirkes KA. 1979. Yellow sugarcane aphid: plant resistance in cereal crops. Journal of Economic Entomology 72: 486-488. 